\title{
Highly stereoselective synthesis of steroidal 2,5-diketopiperazines based on isocyanide chemistry
}

\author{
Andrea C. Bruttomesso *, Javier Eiras, Javier A. Ramírez, Lydia R. Galagovsky \\ Departamento de Química Orgánica and UMYMFOR (CONICET-Facultad de Ciencias Exactas y Naturales), Universidad de Buenos Aires, Pabellón 2, Piso 3, \\ Ciudad Universitaria, C1428EGA, Buenos Aires, Argentina
}

\section{A R T I C L E I N F O}

\section{Article history:}

Received 6 March 2009

Revised 26 March 2009

Accepted 31 March 2009

Available online 5 April 2009

Keywords:

2,5-Diketopiperazines

Heterocyclic steroids

Multicomponent reaction

Ugi reaction

\begin{abstract}
A B S T R A C T
In this Letter we report that the Ugi reaction/cyclization sequence on a steroidal 17-carboxaldehyde leads to novel steroidal 2,5-diketopiperazines with a noteworthy stereoselectivity. A wide variety in the substitution pattern in the heterocyclic moiety was easily achieved by changing the components in the Ugi reaction.
\end{abstract}

(c) 2009 Elsevier Ltd. All rights reserved.
The enzyme $17 \alpha$-hydroxylase/17,20-lyase (17 $\alpha$-lyase or CYP17) is a cytochrome $\mathrm{P}-450$ that catalyzes the conversion of progesterone and pregnenolone into androgens. ${ }^{1}$ The potential therapeutic value of $17 \alpha$-lyase inhibitors in the treatment of androgen-dependent diseases, for example, prostate cancer, has led to much interest. $^{2}$ A number of steroidal inhibitors of CYP17, many of which contain a heterocycle at C-17 (Fig. 1), have been described. ${ }^{3-5}$

2,5-Diketopiperazine is the smallest possible cyclic peptide consisting of two $\alpha$-amino acid residues. This highly constrained scaffold is present in a large number of biologically active compounds and serves as a privileged structure in medicinal chemistry. 6,7

Many different syntheses of ketopiperazines have been described in the past; however, multicomponent reactions (MCRs) seem to be particularly well suited to assemble piperazines, since more than 10 different methods have been published so far. ${ }^{8}$

Recently, Marcaccini et al. have described an interesting approach toward 2,5-diketopiperazines. ${ }^{9}$ An Ugi four-component reaction (U-4CR) between amines, aldehydes, chloroacetic acid, and isocyanides affords the Ugi intermediate, which is cyclized to the title compounds upon treatment with ethanolic $\mathrm{KOH}$ under ultrasonication. A limitation of this synthesis is that the U-4CR products arising from aliphatic aldehydes give only complex reaction mixtures during the cyclization.

\footnotetext{
* Corresponding author. Tel.: +54 01145763346; fax: +54 01145763385.

E-mail addresses: aachiocc@qo.fcen.uba.ar, andrea.bruttomesso@gmail.com (A.C. Bruttomesso).
}

In this Letter we report the application of this procedure for the synthesis of novel steroids bearing a 2,5-diketopiperazine moiety at $\mathrm{C}-17$.

The synthesis started with the steroidal aldehyde $\mathbf{1}$, which can be obtained from dehydroepiandrosterone (DHEA) in four steps by following a described procedure. ${ }^{10}$ The U-4CR of this aldehyde with 2-chloroacetic acid, an amine, and an isonitrile gave the adducts $\mathbf{2 a - 9 a}$ as the only products. ${ }^{11}$ These intermediates were treated with $\mathrm{KOH}$ in ethanol under ultrasound irradiation ${ }^{12}$ to give the desired steroidal diketopiperazines $\mathbf{2 b - 9 b}$, substituted at both nitrogen atoms (Scheme 1).

Although Marcaccini et al. have found that the cyclization step is unsuccessful when an aliphatic aldehyde is employed, in our case the sequence took place smoothly and in good yields (Table 1).

The stereochemistry of the new asymmetric center (C-3') was established from NMR experiments. Firstly, all the resonances were completely assigned using 1D and 2D NMR spectra, and the NOE's between diagnostic protons were determined. In every case a correlation between the $\mathrm{C}-18$ protons and the $\mathrm{C}-3^{\prime}$ proton was

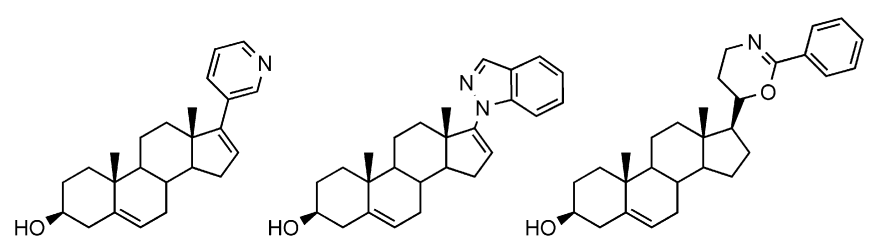

Figure 1. Chemical structures of CYP17 inhibitors. 
<smiles>CC12CCC3C(C=C4CC(O)CCC43)CCC1C1CC(=O)CCC12C</smiles>

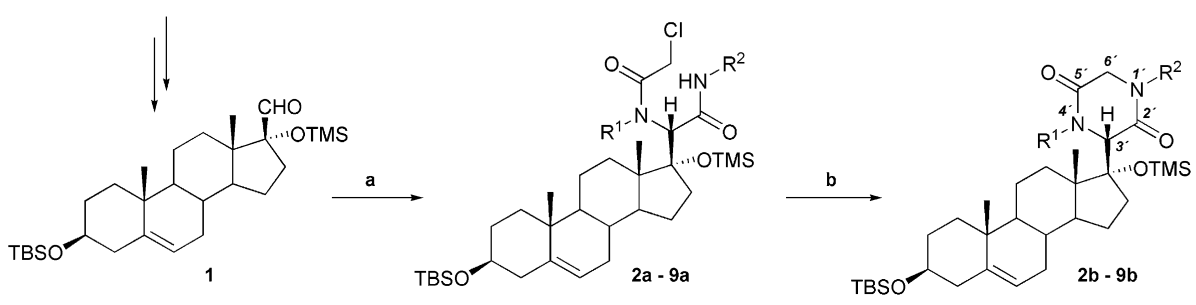

Scheme 1. General synthetic procedure: Reagents and conditions: (a) $\mathrm{ClCH}_{2} \mathrm{COOH}, \mathrm{R}^{1} \mathrm{NH}_{2}, \mathrm{R}^{2} \mathrm{NC}$, EtOH or MeOH, rt; (b) KOH, EtOH, ultrasound irradiation, rt.

Table 1

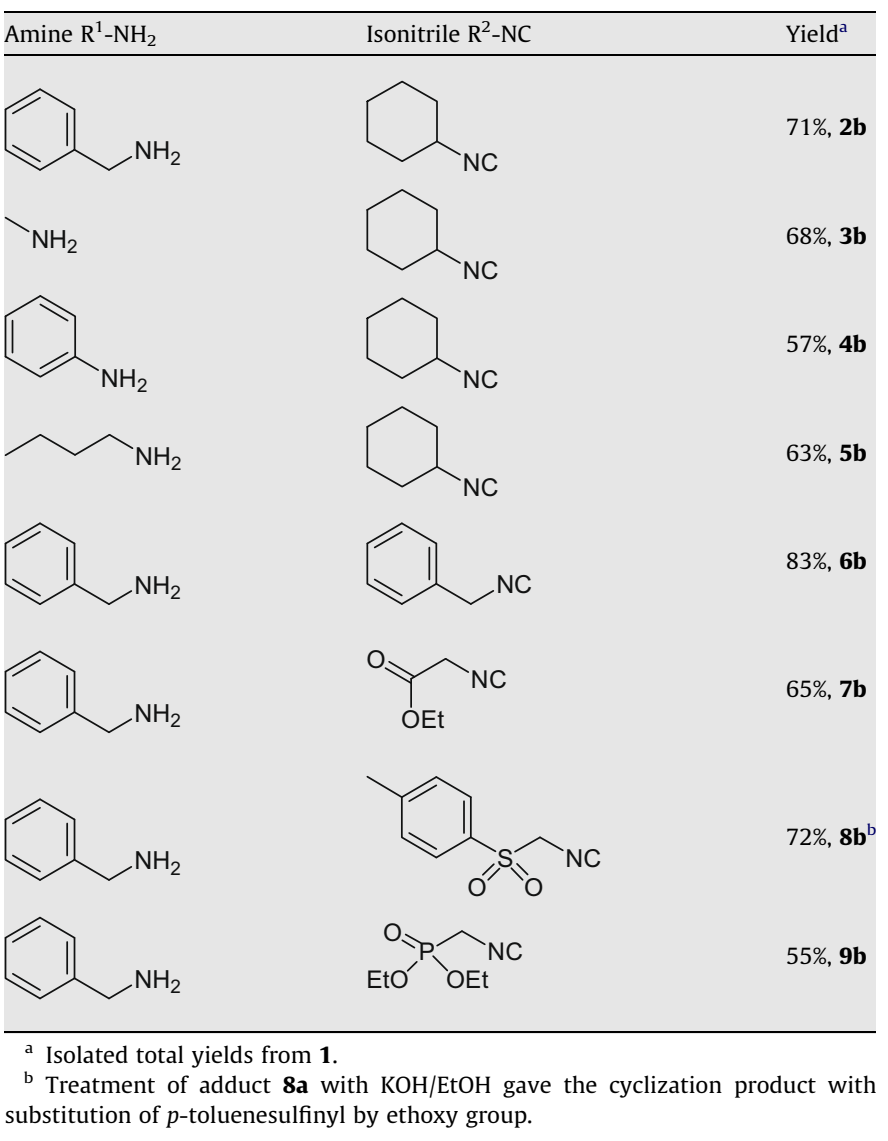

observed. Moreover, the NOESY spectra showed correlations between the protons belonging to the substituents at $\mathrm{N}-1^{\prime}$ or/and the $C-6^{\prime}$ with the trimethylsilyl moiety, whereas protons at C-18 correlated with those of the substituents at $\mathrm{N}-4^{\prime}$, confirming the $S$ stereochemistry at $C-3^{\prime}$. As an example, Figure 2 depicts these correlations for compound $\mathbf{2 b}$.

Any of the four components can in principle, if chiral, control the generation of the new stereogenic center. Taking into consideration that the U-4CR reaction usually suffers from a low stereoselectivity, even with aldehydes that are known to give excellent asymmetric induction in the reaction with other kinds of C-nucleophiles, our results are noteworthy. ${ }^{13}$

The stereochemical outcome was the same in each case, irrespective of the amine or isonitrile employed. This suggests that the asymmetry is induced by the rigid steroidal frame.

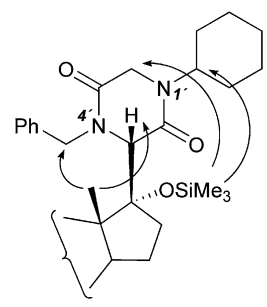

Figure 2. NOE correlations for compound $\mathbf{2 b}$.

Three possible competing mechanisms have been proposed. ${ }^{13}$ In our case two of these could be working. On one side, the direct attack of the isocyanide from the less hindered face of the protonated $E$-imine. On the other side the iminium ion is attacked first by the carboxylate to give a thermodynamic intermediate stabilized by intramolecular hydrogen-bond and then the substitution by the isocyanide proceeds with inversion of configuration. In both case the rate-limiting step is the isocyanide attack pathway, leading to an adduct with $\mathrm{S}$ stereochemistry at $\mathrm{C}-3^{\prime}{ }^{13,14}$

In order to rationalize our results, we performed a conformational search for the protonated $E$-imine from 1 and methylamine, putative intermediate in the formation of $\mathbf{3 b}$, looking for the lower energy conformations. ${ }^{15}$ Figure 3 shows that both the $\mathrm{CH}_{3}-18$ and the steroidal skeleton block the Si-face of the imine, inducing the observed attack.

In conclusion, in the present work we show that this synthetic sequence is suitable for the synthesis of the 2,5-diketopiperazine scaffold attached to the $\mathrm{C}-17$ of the steroidal nucleus. Furthermore, a wide variety in the substitution pattern in the heterocycle can be easily achieved by changing the components in the U-4CR. Notably, the synthesis resulted to have a high stereoselectivity.

The use of steroids in multicomponent reactions leading to heterocyclic compounds has not been fully exploited yet. ${ }^{16,17}$ Thus, further studies are under way to expand this methodology to other steroids and heterocycles.

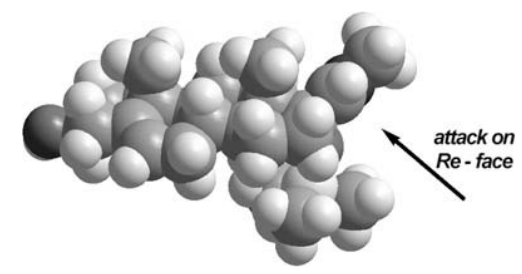

Figure 3. Optimized conformation of the $E$-imine intermediate in the formation of 3b. Observed attack. 


\section{Acknowledgments}

This work was supported by Grants from the Universidad de Buenos Aires (UBACyT X-84) and the Agencia Nacional de Promoción Científica y Técnica (ANPCyT PICT 2007-00914). We are grateful to UMYMFOR (UBA-CONICET) for the analytical and spectroscopic determinations.

\section{References and notes}

1. Nakajin, S.; Hall, P. F. Biochemistry 1981, 20, 4037-4042.

2. Bruno, R. D.; Njar, V. C. O. Bioorg. Med. Chem. 2007, 15, 5047-5060.

3. Clement, O. O.; Freeman, C. M.; Hartmann, R. W.; Handratta, V. D.; Vasaitis, T. S.; Brodie, A. M. H.; Njar, V. C. O. J. Med. Chem. 2003, 46, 2345-2351.

4. Wölfling, J.; Oravecz, O. A.; Ondré, D.; Mernyák, E.; Schneider, G.; Tóth, I.; Szécsi, M.; Julesz, J. Steroids 2006, 71, 809-816.

5. Moreira, V. M. A.; Vasaitis, T. S.; Njar, V. C. O.; Salvador, J. A. R. Steroids 2007, 939-948.

6. Donkor, I. O.; Sanders, M. L. Bioorg. Med. Chem. Lett. 2001, 11, 2647-2649.

7. Nam, N.-H.; Ye, G.; Sun, G.; Parang, K. J. Med. Chem. 2004, 47, 3131-3141.

8. Marcaccini, S.; Torroba, T. In Multicomponent Reactions; Zhu, J., Bienyamé, H., Eds.; Wiley-VCH: Weinheim, 2005; pp 33-75.

9. Marcaccini, S.; Pepino, R.; Pozo, M. C. Tetrahedron Lett. 2001, 42, 2727-2728.

10. Schor, L.; Gros, E. G.; Seldes, A. M. J. Chem. Soc., Perkin Trans. I 1992, 453-454.

11. General synthetic procedure: The carboxaldehyde $1(90 \mathrm{mg}, 0.18 \mathrm{mmol})$ was dissolved in methanol or ethanol $(5 \mathrm{~mL})$ and 1 equiv of the amine and 2chloroacetic acid was added. The mixture was stirred for $15 \mathrm{~min}$ at room temperature and 1 equiv of the isonitrile was added. The reaction mixture was maintained at room temperature for $6 \mathrm{~h}$. The solvent was evaporated under reduced pressure and the residue was taken in dichloromethane and purified by silica gel column chromatography (hexane/EtOAc gradient). Data for compound 2a, 87\% yield; colorless solid; mp $172-174{ }^{\circ} \mathrm{C} ;{ }^{1} \mathrm{H}$ NMR $\left(\mathrm{CDCl}_{3}\right.$, $500 \mathrm{MHz}) \delta 0.06\left(\left(\mathrm{CH}_{3}\right)_{2} \mathrm{SiO}, 6 \mathrm{H}, \mathrm{s}\right), 0.17\left(\left(\mathrm{CH}_{3}\right)_{3} \mathrm{SiO}, 9 \mathrm{H}, \mathrm{s}\right), 0.8(18-\mathrm{H}, 3 \mathrm{H}, \mathrm{s})$, $0.89\left(\left(\mathrm{CH}_{3}\right)_{3} \mathrm{CSiO}, 9 \mathrm{H}, \mathrm{s}\right), 1.01(19-\mathrm{H}, 3 \mathrm{H}, \mathrm{s}), 3.50(3-\mathrm{H}, 1 \mathrm{H}, \mathrm{m}), 3.66(-\mathrm{CONHCH}-$, $1 \mathrm{H}, \mathrm{m}), 3.69\left(-\mathrm{COCH}_{a} \mathrm{H}_{\mathrm{b}} \mathrm{Cl}, 1 \mathrm{H}, \mathrm{d}, J=12.7 \mathrm{~Hz}\right), 3.91\left(-\mathrm{COCH}_{\mathrm{a}} \mathrm{H}_{\mathrm{b}} \mathrm{Cl}, 1 \mathrm{H}, \mathrm{d}\right.$, $J=12.7 \mathrm{~Hz}), 4.47\left(-\mathrm{NCH}_{\mathrm{a}} \mathrm{H}_{\mathrm{b}} \mathrm{Ph}, 1 \mathrm{H}, \mathrm{d}, J=18.0 \mathrm{~Hz}\right), 5.13(-\mathrm{NHCOCHN}-, 1 \mathrm{H}, \mathrm{s})$, $5.33(6-\mathrm{H}, 1 \mathrm{H}, \mathrm{d}, J=5.2 \mathrm{~Hz}), 5.98\left(-\mathrm{NCH}_{\mathrm{a}} H_{\mathrm{b}} \mathrm{Ph}, 1 \mathrm{H}, \mathrm{d}, J=18.0 \mathrm{~Hz}\right), 6.11(-$
CONHCH-, $1 \mathrm{H}, \mathrm{d}, J=6.1 \mathrm{~Hz}), 7.04(\mathrm{Ar}, 2 \mathrm{H}, \mathrm{d}, J=7.5 \mathrm{~Hz}), 7.23(\mathrm{Ar}, 3 \mathrm{H}, \mathrm{m}) \mathrm{ppm}$; ${ }^{13} \mathrm{C} \mathrm{NMR}\left(\mathrm{CDCl}_{3}, 500 \mathrm{MHz}\right) \delta-4.6\left(\left(\mathrm{CH}_{3}\right)_{2} \mathrm{SiO}\right), 2.9\left(\left(\mathrm{CH}_{3}\right)_{3} \mathrm{SiO}\right), 15.1(\mathrm{C} 18), 18.3$ (( $\left.\left.\mathrm{CH}_{3}\right)_{3} \mathrm{CSiO}\right), 19.4$ (C19), 20.8, 23.4, 24.8, 24.7, 25.5, $25.9\left(\left(\mathrm{CH}_{3}\right)_{3} \mathrm{CSiO}\right), 30.9$, $32.0,32.2,32.9,33.3,34.5,36.6(\mathrm{C} 10), 37.3,42.3\left(-\mathrm{COCH}_{2} \mathrm{Cl}\right), 42.8,47.8$ (-CONHCH-), $48.9(\mathrm{C} 13), 49.6\left(-\mathrm{NCH}_{2} \mathrm{Ph}\right), 49.8,50.1,58.1$ (-NHCOCHN-), 72.6 (C3), 90.5 (C17), 120.8 (C6), 125.3, 127.0, 128.8, 138.4, 141.8 (C5), 166.7 $(-\mathrm{NHCOCH}-), 169.3\left(-\mathrm{COCH}_{2} \mathrm{Cl}\right) \mathrm{ppm}$. Anal. Calcd for $\mathrm{C}_{45} \mathrm{H}_{73} \mathrm{ClN}_{2} \mathrm{O}_{4}: \mathrm{C}, 67.76$ H, 9.22; N, 3.51. Found: C, 67.71; H, 9.24; N, 3.56.

12. General synthetic procedure: Compounds $\mathbf{2 a - 9 a}(100 \mathrm{mg})$ were treated with a solution of $\mathrm{KOH}(100 \mathrm{mg})$ in EtOH $(10 \mathrm{ml})$. The resulting suspension was transferred to the vessel and ultrasonicated at room temperature for $30 \mathrm{~min}$. The solvent was evaporated under reduced pressure and the residue was taken in dichloromethane and purified by silica gel column chromatography

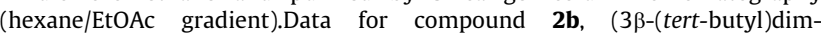
ethylsilyloxy-17 $\beta-\left\{3^{\prime}\left[\left(1^{\prime}\right.\right.\right.$-cyclohexyl-4'-benzyl $)-2^{\prime}, 5^{\prime}$-diketopiperazinyl $\left.]\right\}-17 \alpha$ trimethylsililoxy androstane) $82 \%$ yield; colorless solid; mp $111-112{ }^{\circ} \mathrm{C} ;{ }^{1} \mathrm{H}$ $\operatorname{NMR}\left(\mathrm{CDCl}_{3}, 500 \mathrm{MHz}\right) \delta 0.06\left(\left(\mathrm{CH}_{3}\right)_{2} \mathrm{SiO}, 6 \mathrm{H}, \mathrm{s}\right), 0.21\left(\left(\mathrm{CH}_{3}\right)_{3} \mathrm{SiO}, 9 \mathrm{H}, \mathrm{s}\right), 0.8$ $(18-\mathrm{H}, 3 \mathrm{H}, \mathrm{s}), 0.89\left(\left(\mathrm{CH}_{3}\right)_{3} \mathrm{CSiO}, 9 \mathrm{H}, \mathrm{s}\right), 1.01(19-\mathrm{H}, 3 \mathrm{H}, \mathrm{s}), 3.50(3-\mathrm{H}, 1 \mathrm{H}, \mathrm{m}), 3.68$ $\left(-\mathrm{NCH}_{\mathrm{a}} \mathrm{H}_{\mathrm{b}} \mathrm{Ph}, 1 \mathrm{H}, \mathrm{d}, J=15.5 \mathrm{~Hz}\right), 3.88\left(-\mathrm{COCH}_{\mathrm{a}} \mathrm{H}_{\mathrm{b}} \mathrm{N}, 1 \mathrm{H}, \mathrm{d}, J=16.5 \mathrm{~Hz}\right), 3.93$ $\left(-\mathrm{COCH}_{\mathrm{a}} \mathrm{H}_{\mathrm{b}} \mathrm{N}, 1 \mathrm{H}, \mathrm{d}, J=16.5 \mathrm{~Hz}\right), 4.01(-\mathrm{NCOCHN}-, 1 \mathrm{H}, \mathrm{s}), 4.31\left(-\mathrm{COCH}_{2} \mathrm{NCH}-\right.$ $1 \mathrm{H}, \mathrm{m}), 5.33(6-\mathrm{H}, 1 \mathrm{H}, \mathrm{d}, J=5.2 \mathrm{~Hz}), 5.54\left(-\mathrm{NCH}_{\mathrm{a}} \mathrm{H}_{\mathrm{b}} \mathrm{Ph}, 1 \mathrm{H}, \mathrm{d}, J=15.5 \mathrm{~Hz}\right), 7.11$ $(\mathrm{Ar}, 2 \mathrm{H}, \mathrm{d}, J=7.5 \mathrm{~Hz}), 7.27(\mathrm{Ar}, 3 \mathrm{H}, \mathrm{m}) \mathrm{ppm} ;{ }^{13} \mathrm{C} \mathrm{NMR}(\mathrm{CDCl} 3,500 \mathrm{MHz}) \delta-4.6$ $\left(\left(\mathrm{CH}_{3}\right)_{2} \mathrm{SiO}\right), 3.0\left(\left(\mathrm{CH}_{3}\right)_{3} \mathrm{SiO}\right), 15.2(\mathrm{C} 18), 18.3\left(\left(\mathrm{CH}_{3}\right)_{3} \mathrm{CSiO}\right), 19.4$ (C19), 20.5 23.9, 25.3, 25.5, $25.9\left(\left(\mathrm{CH}_{3}\right)_{3} \mathrm{CSiO}\right), 29.5,29.9,30.1,31.8,32.1,32.3,34.0,36.7$ (C10), 37.4, 42.8, 45.6 $\left(-\mathrm{COCH}_{2} \mathrm{~N}\right), 49.0\left(-\mathrm{NCH}_{2} \mathrm{Ph}\right), 49.1(\mathrm{C} 13), 49.3,50.1,52.5$ $\left(-\mathrm{COCH}_{2} \mathrm{NCH}-\right), 62.6$ (-NCOCHN-), 72.5 (C3), 89.8 (C17), 120.7 (C6), 127.3, 127.6, 128.9, 136.0, 141.8 (C5), $166.4(-\mathrm{NCOCHN}-), 166.8\left(-\mathrm{COCH}_{2} \mathrm{~N}\right) \mathrm{ppm}$. Anal. Calcd for $\mathrm{C}_{45} \mathrm{H}_{72} \mathrm{~N}_{2} \mathrm{O}_{4} \mathrm{Si}_{2}$ : C, 71.00; H, 9.53; N, 3.68. Found: C, 70.97; $\mathrm{H}$, 9.56; N, 3.65.

13. Banfi, L.; Basso, A.; Guanti, G.; Riva, R. In Multicomponent Reactions; Zhu, J. Bienyamé, H., Eds.; Wiley-VCH: Weinheim, 2005; pp 1-32.

14. Marcaccini, S.; Torroba, T. Nat. Protocol. 2007, 2, 632-639.

15. Molecular modeling: A random conformational search of the lowest energy structures was performed for the model using the Tripos Molecular Field as implemented in the SYBYL 7.2 software. The selected conformation was optimized in vacuo at the B3LYP/6-31G (d,p) level by using GAUSSIAN98 and proved to be a local minimum via normal mode analysis.

16. Dömling, A.; Kehagia, K.; Ugi, I. Tetrahedron 1995, 51, 9519-9522.

17. Alonso, F.; Acebedo, S. L.; Bruttomesso, A. C.; Ramírez, J. A. Steroids 2008, 73 1270-1276. 